\title{
High-resolution hybrid inversion of IASI ammonia columns to constrain US ammonia emissions using the CMAQ adjoint model
}

\author{
Yilin Chen ${ }^{1}$, Huizhong Shen ${ }^{1}$, Jennifer Kaiser ${ }^{1,2}$, Yongtao Hu ${ }^{1}$, Shannon L. Capps ${ }^{3}$, Shunliu Zhao ${ }^{4}$, Amir Hakami ${ }^{4}$, \\ Jhih-Shyang Shih ${ }^{5}$, Gertrude K. Pavur ${ }^{1}$, Matthew D. Turner ${ }^{6}$, Daven K. Henze ${ }^{7}$, Jaroslav Resler ${ }^{8}$, \\ Athanasios Nenes ${ }^{9,10}$, Sergey L. Napelenok ${ }^{11}$, Jesse O. Bash ${ }^{11}$, Kathleen M. Fahey ${ }^{11}$, Gregory R. Carmichael ${ }^{12}$, \\ Tianfeng Chai ${ }^{13}$, Lieven Clarisse ${ }^{14}$, Pierre-François Coheur ${ }^{14}$, Martin Van Damme ${ }^{14}$, and Armistead G. Russell ${ }^{1}$ \\ ${ }^{1}$ School of Civil and Environmental Engineering, Georgia Institute of Technology, Atlanta, GA 30332, United States \\ ${ }^{2}$ School of Earth and Atmospheric Sciences, Georgia Institute of Technology, Atlanta, GA 30332, United States \\ ${ }^{3}$ Department of Civil, Architectural, and Environmental Engineering, Drexel University, \\ Philadelphia, PA 19104, United States \\ ${ }^{4}$ Department of Civil and Environmental Engineering, Carleton University, Ottawa, Ontario K1S5B6, Canada \\ ${ }^{5}$ Resources for the Future, Washington, D.C. 20036, USA \\ ${ }^{6}$ SAIC, Stennis Space Center, MS 39529, USA \\ ${ }^{7}$ Mechanical Engineering Department, University of Colorado, Boulder, CO 80309, USA \\ ${ }^{8}$ Institute of Computer Science of the Czech Academy of Sciences, Prague, 182 07, Czech Republic \\ ${ }^{9}$ Institute for Chemical Engineering Sciences, Foundation for Research and Technology Hellas, Patras, 26504, Greece \\ ${ }^{10}$ School of Architecture, Civil \& Environmental Engineering, Ecole polytechnique fédérale de Lausanne, \\ 1015, Lausanne, Switzerland \\ ${ }^{11}$ Atmospheric \& Environmental Systems Modeling Division, U.S. EPA, Research Triangle Park, NC 27711, USA \\ ${ }^{12}$ Department of Chemical and Biochemical Engineering, University of Iowa, Iowa City, IA 52242, USA \\ ${ }^{13}$ NOAA Air Resources Laboratory (ARL), Cooperative Institute for Satellites Earth System Studies (CISESS), \\ University of Maryland, College Park, MD 20740, USA \\ ${ }^{14}$ Université libre de Bruxelles (ULB), Spectroscopy, Quantum Chemistry and \\ Atmospheric Remote Sensing (SQUARES), Brussels, Belgium
}

Correspondence: Armistead G. Russell (ar70@ce.gatech.edu)

Received: 28 May 2020 - Discussion started: 29 June 2020

Revised: 3 January 2021 - Accepted: 5 January 2021 - Published: 11 February 2021

\begin{abstract}
Ammonia $\left(\mathrm{NH}_{3}\right)$ emissions have large impacts on air quality and nitrogen deposition, influencing human health and the well-being of sensitive ecosystems. Large uncertainties exist in the "bottom-up" $\mathrm{NH}_{3}$ emission inventories due to limited source information and a historical lack of measurements, hindering the assessment of $\mathrm{NH}_{3}$-related environmental impacts. The increasing capability of satellites to measure $\mathrm{NH}_{3}$ abundance and the development of modeling tools enable us to better constrain $\mathrm{NH}_{3}$ emission estimates at high spatial resolution. In this study, we constrain the $\mathrm{NH}_{3}$ emission estimates from the widely used $2011 \mathrm{Na}$ tional Emissions Inventory (2011 NEI) in the US using Infrared Atmospheric Sounding Interferometer $\mathrm{NH}_{3}$ column
\end{abstract}

density measurements (IASI-NH ${ }_{3}$ ) gridded at a $36 \mathrm{~km}$ by $36 \mathrm{~km}$ horizontal resolution. With a hybrid inverse modeling approach, we use the Community Multiscale Air Quality Modeling System (CMAQ) and its multiphase adjoint model to optimize $\mathrm{NH}_{3}$ emission estimates in April, July, and October. Our optimized emission estimates suggest that the total $\mathrm{NH}_{3}$ emissions are biased low by $26 \%$ in $2011 \mathrm{NEI}$ in April with overestimation in the Midwest and underestimation in the Southern States. In July and October, the estimates from NEI agree well with the optimized emission estimates, despite a low bias in hotspot regions. Evaluation of the inversion performance using independent observations shows reduced underestimation in simulated ambient $\mathrm{NH}_{3}$ concentra- 
tion in all 3 months and reduced underestimation in $\mathrm{NH}_{4}^{+}$wet deposition in April. Implementing the optimized $\mathrm{NH}_{3}$ emission estimates improves the model performance in simulating $\mathrm{PM}_{2.5}$ concentration in the Midwest in April. The model results suggest that the estimated contribution of ammonium nitrate would be biased high in a priori NEI-based assessments. The higher emission estimates in this study also imply a higher ecological impact of nitrogen deposition originating from $\mathrm{NH}_{3}$ emissions.

\section{Introduction}

Ammonia $\left(\mathrm{NH}_{3}\right)$ emissions play a major role in ambient aerosol formation and reactive nitrogen deposition (Stevens, 2019: Houlton et al., 2013). However, our understanding of $\mathrm{NH}_{3}$ sources and sinks is limited by the large uncertainties present in the $\mathrm{NH}_{3}$ emissions inventories (Xu et al., 2019; McQuilling and Adams, 2015). In chemical transport models, uncertainties in $\mathrm{NH}_{3}$ emissions propagate into the dynamic modeling of the atmospheric transport, chemistry, and deposition of $\mathrm{NH}_{3}$, other reactive nitrogen species, and other key atmospheric constituents associated with $\mathrm{NH}_{3}$ (Heald et al., 2012; Paulot et al., 2013; Kelly et al., 2014; Zhang et al., 2018b), hindering an accurate assessment of the various $\mathrm{NH}_{3}$-related environmental impacts and the associated sources. The large uncertainties in the $\mathrm{NH}_{3}$ emission inventories are partially due to a lack of sufficient in situ $\mathrm{NH}_{3}$ measurements that could be used to constrain emission estimates (Zhu et al., 2015).

Emerging satellite observations of gaseous $\mathrm{NH}_{3}$ provide a unique opportunity to better constrain the bottom-up $\mathrm{NH}_{3}$ emission estimates for both their spatial distribution and seasonality. Bottom-up inventories calculate the $\mathrm{NH}_{3}$ emissions based on estimated activity levels and corresponding emission factors, both of which are subject to high uncertainties, particularly for agricultural sources, the major contributor (Cooter et al., 2012; McQuilling and Adams, 2015). Several studies have utilized $\mathrm{NH}_{3}$ column density retrieved from the Infrared Atmospheric Sounding Interferometer (IASI) (Clarisse et al., 2009; Van Damme et al., 2015b) or the Atmospheric Infrared Sounder (AIRS; Warner et al., 2016) as well as the inferred surface mixing ratio of $\mathrm{NH}_{3}$ from the Crosstrack Infrared Sounder (CrIS; Shephard and Cady-Pereira, 2015; Shephard et al., 2020) to characterize the spatiotemporal distribution of $\mathrm{NH}_{3}$. These satellite measurements are useful for supplementing emission inventories to identify and quantify underestimated or missing emission hotspots, especially in intensive agricultural zones (Van Damme et al., 2018; Dammers et al., 2019; Clarisse et al., 2019). These studies find that the satellite-derived emission estimates are often twice as much as the bottom-up estimates on a regional scale and can be over 10 times higher over hotspots. However, the $\mathrm{NH}_{3}$ retrievals from satellites are also subject to large uncertainties when the signal-to-noise ratio is low, which limits their ability to accurately measure $\mathrm{NH}_{3}$ columns in low-emission areas (Clarisse et al., 2010; Van Damme et al., 2015a).

Inverse-modeling-based optimization combines the information from a priori emission inventories and observations and allows us to use the information from both. As one of the inverse modeling methods, the four-dimensional variational assimilation (4D-Var) method seeks the best emission estimate by minimizing a cost function that measures the differences between observations and model predictions, as well as the differences between a prior and adjusted emission estimates. 4D-Var can be computationally expensive at fine model resolutions or with a large set of observations to be assimilated (Brasseur and Jacob, 2017). Recent studies have taken advantage of the implementation of the adjoint technique in the chemical transport models to conduct 4D-Var for optimizing emissions estimation (Zhu et al., 2013; Paulot et al., 2014; Zhang et al., 2018c). The adjoint-based inversion method calculates the gradients of a cost function analytically and searches for the solution using a steepest-descent optimization algorithm through iterating (Brasseur and Jacob, 2017). By testing the performance of the inverse modeling method using artificial observational data, Li et al. (2019) proposed that a two-step optimization process, which combines the iterative mass balance (IMB) method and the 4DVar method, can further reduce the computational cost. The IMB method assumes a linear relationship between the $\mathrm{NH}_{3}$ column density and local $\mathrm{NH}_{3}$ emission and searches for the emission scaling factors iteratively until the simulated $\mathrm{NH}_{3}$ column density converges to the observations. At a coarse $\left(2^{\circ} \times 2.5^{\circ}\right)$ resolution, the IMB method is as effective as the 4D-Var method and requires two-thirds less computational time. In the second step, emission scaling factors obtained from the IMB method with a coarser resolution are used as an initial starting point for the 4D-Var optimization process to reduce the overall computational time (Li et al., 2019).

This work utilizes satellite observations from the IASI$\mathrm{NH}_{3}$ column density measurements (IASI-NH $\mathrm{N}_{3}$ ) (Clarisse et al., 2009; Van Damme et al., 2017), to provide a highresolution, optimized $\mathrm{NH}_{3}$ emission inventory for the US developed using an adjoint inverse modeling technique ( $\mathrm{Li}$ et al., 2019), the robustness of which is demonstrated by evaluation against multiple independent in situ measurements. The IASI- $\mathrm{NH}_{3}$ dataset was applied to optimize $\mathrm{NH}_{3}$ emission estimates from the 2011 National Emissions Inventory (2011 NEI) using the Community Multiscale Air Quality Modeling System (CMAQ) and its adjoint model at a $36 \mathrm{~km} \times 36 \mathrm{~km}$ resolution. The multiphase adjoint model for CMAQ v5.0 was developed recently, including full adjoints for gas-phase chemistry, aerosols, cloud process, diffusion, and advection (Zhao et al., 2020). Both process-by-process and full adjoint model evaluations show reasonable accuracy based on agreements between the adjoint sensitivities and forward sensitivities (Zhao et al., 2020). Previous inversion-based $\mathrm{NH}_{3}$ 
emission constraints using in situ measures are limited by the spatial coverage and representativeness of the measurements (Gilliland et al., 2006; Henze et al., 2009; Paulot et al., 2014;). Zhu et al. (2013) first attempted to optimize the $\mathrm{NH}_{3}$ emission inventory using $\mathrm{NH}_{3}$ derived from the Tropospheric Emission Spectrometer satellite at $2^{\circ} \times 2.5^{\circ}$ resolution (Zhu et al., 2013). Inverse modeling at such a coarse resolution is limited to refining regional emissions. Similar to the inversion using CrIS $\mathrm{NH}_{3}$ measurements (Cao et al., 2020), inversion with the IASI-NH${ }_{3}$ dataset allows us to perform the optimization at a finer resolution with its daily global spatial coverage. Furthermore, the hybrid inversion approach adopted in this study allows us to calculate full adjoint sensitivities online instead of using approximated sensitivities from the offline simulations (Zhu et al., 2013; Cao et al., 2020). The performance of our optimized estimates and the $2011 \mathrm{NEI}$ are evaluated and compared based on in situ observed ambient $\mathrm{NH}_{3}$ concentrations and $\mathrm{NH}_{4}^{+}$wet deposition. Finally, by substituting the a priori $\mathrm{NH}_{3}$ emissions with the optimized emissions, we assess the subsequent changes in simulated ambient $\mathrm{PM}_{2.5}$ concentrations and nitrogen deposition exceedances.

\section{Materials and methods}

\subsection{IASI-NH 3 observations}

$\mathrm{NH}_{3}$ column densities retrieved from IASI on board the Metop-A satellite are assimilated to constrain spatially resolved $\mathrm{NH}_{3}$ emissions using the $2011 \mathrm{NEI}$ as the a priori inventory (Clarisse et al., 2009; Van Damme et al., 2014; USEPA, 2014). The polar sun-synchronous satellite has a $12 \mathrm{~km}$ diameter footprint at nadir and a bidaily global coverage. Only observations from the morning pass around 09:30 local standard time (LST) are used due to more favorable thermal contrast and smaller errors as compared to the night pass around 21:30LST. A comparison between the IASI-NH 3 data and ground-based Fourier transform infrared (FTIR) observations shows a correlation between the two with $r=0.8$ and the slope $=0.73$, indicating a tendency of IASI-NH $\mathrm{NH}_{3}$ to underestimate the FTIR observations (Dammers et al., 2016). A comparison between IASI-NH 3 and airborne measurements also indicated an underestimation in California, while the comparison between IASI-NH 3 and ground observation from the Ammonia Monitoring Network (AMoN) indicated an overestimation (Van Damme et al., 2015a; NADP, 2014). Overall, the evaluations show broad consistency between IASI-NH 3 and other independent measurements, with no consistent biases identified. These evaluations were based on previous datasets. Here we use a new version that relies on another retrieval algorithm, which among other things has better performance for measurements under unfavorable conditions (Whitburn et al., 2016; Van Damme et al., 2017).
Specifically, the $\mathrm{NH}_{3}$ products for 2011 from ANNI-NH $\mathrm{H}_{3}$ v2.2R-I datasets were used (Van Damme et al., 2017). The algorithm relies on the conversion of hyperspectral range indices to $\mathrm{NH}_{3}$ column density using a neural network that takes into account 20 input parameters, characterizing temperature, pressure, humidity, and $\mathrm{NH}_{3}$ vertical profiles. A relative uncertainty estimate is provided along with each of the $\mathrm{NH}_{3}$ vertical column densities in the dataset. Small negative columns are possible - and these are valid observations, needed to reduce overall biases in the dataset. As the retrieval is unconstrained, no averaging kernels are calculated. We therefore directly compare the IASI-NH 3 column density with the simulated column density in CMAQ. Such comparison may be biased because the sensitivity of retrieved $\mathrm{NH}_{3}$ column densities to $\mathrm{NH}_{3}$ concentrations is heightdependent (typically peaks around 700-850 hPa) (Dammers et al., 2017; Shephard et al., 2015). Although the CMAQsimulated $\mathrm{NH}_{3}$ columns are also most sensitive to $\mathrm{NH}_{3}$ concentration changes between 700 to $900 \mathrm{hPa}$ (Fig. S1), we cannot quantify the relating uncertainties without knowing the averaging kernels. Without information on averaging kernels, differences between $\mathrm{NH}_{3}$ vertical profiles in CMAQ and the ones used for retrieval may also contribute to the bias between retrieved and modeled column densities, depending on the magnitude of differences (Whitburn et al., 2016).

The retrieved $\mathrm{NH}_{3}$ columns densities are regridded to the $36 \mathrm{~km}$ by $36 \mathrm{~km} \mathrm{CMAQ}$ grid for $4 \mathrm{D}$-Var data assimilation and $216 \mathrm{~km}$ by $216 \mathrm{~km}$ resolution (a six-grid-by-sixgrid CMAQ simulation grid matrix) for iterative mass balance (Fig. 1). The mean column density $\left(\Omega_{o}\right)$ is calculated as the arithmetic mean of all retrievals with their centroids falling in the same grid cell, following the recommendation that the unweighted mean is preferred for the updated version of IASI-NH $\mathrm{NH}_{3}$ as error-weighting can lead to biases (Van Damme et al., 2017). The error (molec $\mathrm{cm}^{-2}$ ) corresponding to the mean column density in each grid is calculated as

$\bar{\sigma}=\sqrt{\frac{\sum\left(\sigma_{i} \times \Omega_{i}\right)^{2}}{n-1}}$,

where $\bar{\sigma}$ is the mean error $\left(\operatorname{molec} \mathrm{cm}^{-2}\right), \Omega_{i}$ is the $i$ th retrieval of $\mathrm{NH}_{3}$ column density from IASI-NH $\mathrm{N}_{3}$ Level 2 data, $\sigma_{i}$ is the relative error associated with each $\Omega_{i}$ as reported, and $n$ is the number of retrievals within each grid cell during the defined time period. For 4D-Var inversion and IMB inversion, daily and monthly means and errors are calculated, respectively.

The observations from April, July, and October are used to constrain the monthly $\mathrm{NH}_{3}$ emission estimates in corresponding months from 2011 NEI. Limited by the high computational cost of adjoint-model-based inversion, the optimization is only performed for the 3 months selected instead of a full year. Observations from winter months are not used because they are too noisy when the thermal contrast is low (Dammers et al., 2016). 

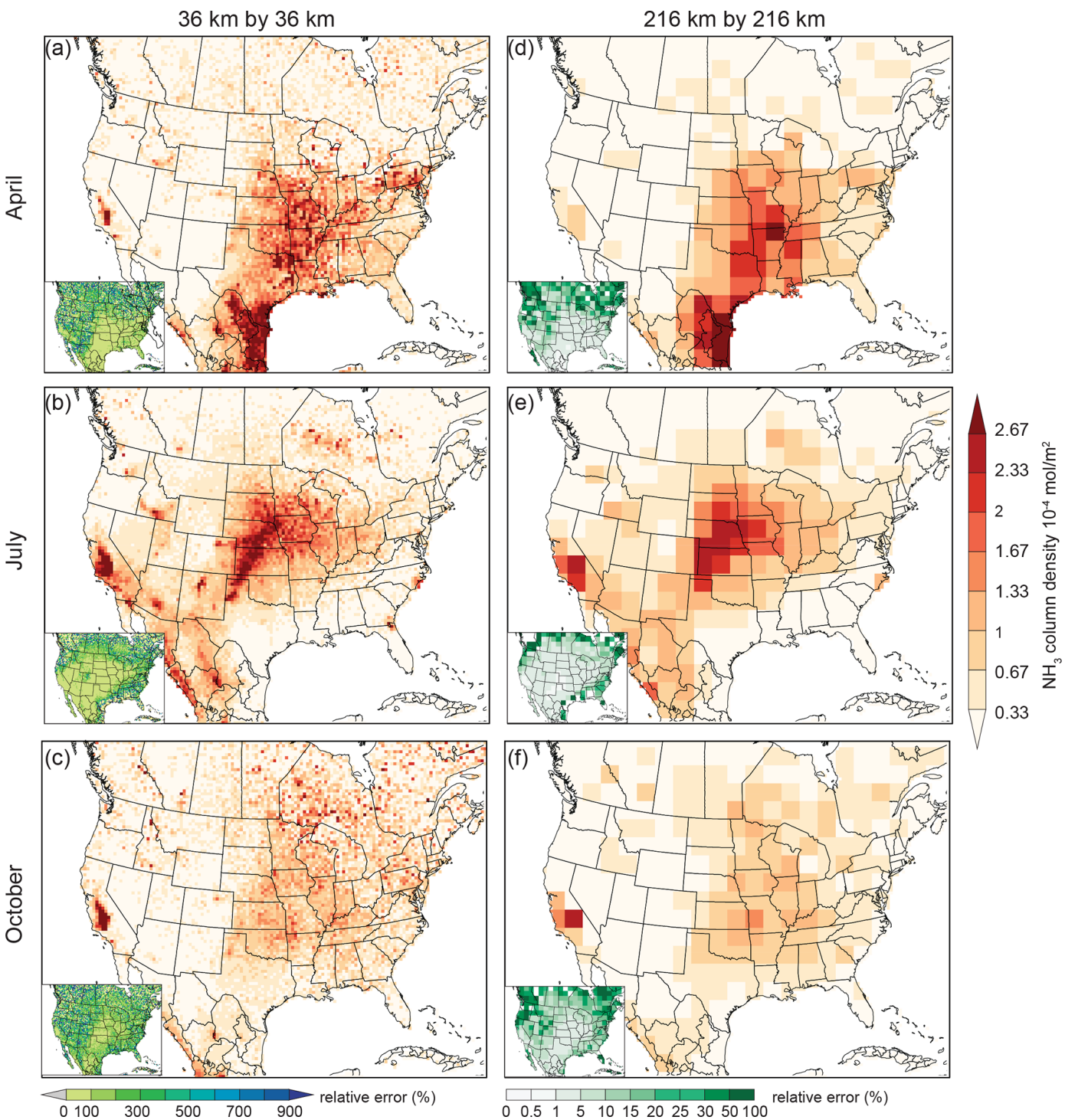

Figure 1. IASI monthly average $\mathrm{NH}_{3}$ column density in April, July, and October 2011 at $36 \mathrm{~km}$ by $36 \mathrm{~km}(\mathbf{a}, \mathbf{b}, \mathbf{c})$ and $216 \mathrm{~km}$ by $216 \mathrm{~km}(\mathbf{d}$, e, f) resolutions within the model simulation domain of this study. The average relative error associated with the column density is shown in the corner of each plot.

\section{$2.2 \mathrm{NH}_{3}$ emission from $2011 \mathrm{NEI}$}

The EPA 2011 NEI is used for a priori emission estimates. Major $\mathrm{NH}_{3}$ sources include livestock waste management, fertilizer application, mobile sources, fire, and fuel combustion, with the majority being emitted by the first two sources. Specifically, the emissions from livestock waste management are estimated based on county-level animal population data and process-based daily emission factors. Emissions from fertilizer applications are estimated based on county-level fertilizer quantities and fixed emission factors, following the CMU Ammonia Model (USEPA, 2015). The $\mathrm{NH}_{3}$ emissions over Mexico and Canada are derived from the simulation results of a fully coupled bi-directional agroecosystem and chemical transport model (FEST_C_EPIC_CMAQ_BIDI) (Shen et al., 2020). Emissions for other species also come from the 2011 NEI.

\subsection{CMAQ and its adjoint}

We use CMAQ v5.0 (Byun and Schere, 2006; USEPA, 2012) and its adjoint (Zhao et al., 2020), driven by meteorological fields produced from the Weather Research and Forecasting (WRF) Model v3.8.1 with grid nudging using the North American Regional Reanalysis dataset (NOAA, 2019). The simulated meteorological fields show good agreement with surface observations (Fig. S2) (NOAA, 2020). The CB05 chemical mechanism was adopted for gas-phase chemistry (Yarwood et al., 2005). The model implements 
ISORROPIA-II in the aerosol module (AERO06) to calculate the gas-particle partitioning of $\mathrm{NH}_{3}$ and $\mathrm{NH}_{4}^{+}$(Fountoukis and Nenes, 2007). The simulation domain covers the contiguous US (CONUS) and part of Canada and Mexico with a $36 \mathrm{~km}$ by $36 \mathrm{~km}$ horizontal resolution and 13 vertical layers extending up to $14.5 \mathrm{kPa}(\sim 16 \mathrm{~km})$ (Fig. 1). To evaluation CMAQ model performance, the simulated gas-particle partitioning ratio of $\mathrm{NH}_{3}-\mathrm{NH}_{4}^{+}$and $\mathrm{NH}_{4}^{+}$deposition is compared with observations from AMoN, the Clean Air Status and Trends Network, and the National Atmospheric Deposition Program (NADP) (Figs. S3 and S4). CMAQ captures the overall spatial pattern of these governing processes for atmospheric $\mathrm{NH}_{3}$ abundance, considering the uncertainties in emissions, model parameters, and meteorological fields. Expanded evaluation of CMAQ model performance in simulating gas-particle partitioning and nitrogen deposition has been conducted in previous studies (Chen et al., 2019, 2020). Monthly simulations are conducted for April, July, and October in 2011 with a $10 \mathrm{~d}$ spin-up for each month.

\subsection{Hybrid inversion approach}

We chose the hybrid inversion approach to combine the advantage of the faster computational speed of the mass balance method and the better optimization performance of the 4DVar method. The first step is to apply the IMB approach to adjust the a priori (2011 NEI) $\mathrm{NH}_{3}$ emission at $216 \mathrm{~km}$ by $216 \mathrm{~km}$ resolution (referred to as the coarse grid hereafter) based on the ratio between the monthly averaged observed $\left(\Omega_{\boldsymbol{o}}\right)$ and simulated $\left(\Omega_{a}\right) \mathrm{NH}_{3}$ column density at the satellite overpassing time, iteratively. At each iteration, the emission in each grid cell is scaled by the ratio following the equation below:

$E_{\mathrm{t}}=\frac{\Omega_{\boldsymbol{o}}}{\Omega_{a}} \times E_{\mathrm{a}}$,

where $E_{\mathrm{t}}$ and $E_{\mathrm{a}}$ are the new and a priori emission estimates, respectively. The method has been described in detail in previous studies (Li et al., 2019; Cooper et al., 2017; Martin et al., 2003). The IMB is applied at the coarse grid so that the $\mathrm{NH}_{3}$ column will be dominated by the local emissions instead of transport from neighboring grids ( $\mathrm{Li}$ et al., 2019). The coarse resolution also reduces the uncertainty associated with IASI-NH $\mathrm{N}_{3}$ as the number of retrievals increases in each grid cell. For grid cells with mean relative error larger than $100 \%$, the satellite observations are considered to be too noisy to provide useful constraints and the a priori emission estimates are retained. The iteration stops when the normalized mean square error either decreases by less than $10 \%$ or begins to increase. The final scaling factor $\left(\varepsilon_{0}\right)$ for each grid cell is the multiplication of the scaling factors derived at each iteration and downscaled to $36 \mathrm{~km}$ by $36 \mathrm{~km}$ resolution by assigning the same value to the six-by-six grid matrix. This scaling factor is applied to the 2011 NEI emissions to create the revised a priori estimate for the $4 \mathrm{D}$-Var inversion.
Next, the 4D-Var inversion is performed. The solution of the optimization problem is sought iteratively by minimizing the cost function $(J)$ defined as the combination of errorweighted, squared difference between the emission scaling factor and unity and the error-weighted, squared difference between IASI-NH $\mathrm{N}_{3}$ and the simulated column density, as below:

$J=\gamma\left(\boldsymbol{\varepsilon} i-\boldsymbol{\varepsilon}_{0}\right)^{T} S_{\mathbf{a}}^{-1}\left(\boldsymbol{\varepsilon}-\boldsymbol{\varepsilon}_{0}\right)+\left(\Omega_{\boldsymbol{o}}-F(\boldsymbol{\varepsilon})\right)^{T}$

$S_{\mathbf{o}}^{-1}\left(\Omega_{\boldsymbol{o}}-F(\varepsilon)\right)$.

$\varepsilon$ is the monthly emission scaling factor to be optimized at each iteration where $\varepsilon=\log \left(E_{\mathrm{t}} / E_{\mathrm{a}}\right)$ on the $36 \mathrm{~km}$ by $36 \mathrm{~km}$ CMAQ grid, consisting of 6104 overland grid cells in the CONUS. $S_{\mathbf{a}}$ and $S_{\mathbf{0}}$ are error covariance matrices for the a priori emission estimates and IASI-NH $\mathrm{NH}_{3}$ retrievals, respectively. With limited information on the spatial correlation of the error covariance, the two matrices are assumed to be diagonal (Paulot et al., 2014; Zhu et al., 2013). For $S_{\mathbf{0}}$, the grid average absolute error is used to represent the observational error. Our test shows that negative $\Omega_{\boldsymbol{o}}$ will lead to a continuous decrease in the adjusted emission for the grid cell because modeled column density cannot become negative. To limit the influence of these negative $\Omega_{\boldsymbol{o}}$, their original weights are multiplied by 0.01 . For $S_{\mathbf{a}}$, the uncertainty in each grid cell is assumed to be $100 \%$ of the a priori emissions. $F(\varepsilon)$ is CMAQ-simulated $\mathrm{NH}_{3}$ column density sampled at the satellite passing time if there is at least one IASI- $\mathrm{NH}_{3}$ retrieval in that grid cell; $\gamma$ is the regularization factor balancing the relative contribution of the a priori emission inventory and IASI-NH $\mathrm{NH}_{3}$ retrievals to the $J$ value. $\gamma$ is chosen to be 800 for April and 500 for July and October based on the L-curve criteria (Hansen, 1999) (Fig. S5).

The gradients of the cost function to $\mathrm{NH}_{3}$ emissions are calculated by the CMAQ adjoint model. In each iteration, the emission-weighted monthly averaged sensitivities in each grid cell are supplied to the L-BFGS-B optimization routine contained in the "optimr" package in R to find the scaling factors that will achieve the minimum of the cost function (Zhu et al., 1997; Byrd et al., 1995). $\mathrm{NH}_{3}$ column density is re-simulated using adjusted emissions by the new set of scaling factors. The iteration process is terminated when the decrease in $J$ is less than $2 \%$ or the local minimum is reached (Li et al., 2019; Zhu et al., 2013).

\subsection{Posterior evaluation}

The posterior emissions are evaluated by comparing the model simulation from optimized emissions with observations. Simulated results are compared with ambient $\mathrm{NH}_{3}$ concentrations from AMoN (NADP, 2014) and the $\mathrm{NH}_{4}^{+}$wet deposition from NADP (NADP, 2019). The simulated $\mathrm{NH}_{3}$ concentration in ppmv is converted to micrograms per cubic meter $\left(\mu \mathrm{g} \mathrm{m}^{-3}\right)$ using local temperature and pressure from the model meteorological inputs. For evaluation against the 
$\mathrm{NH}_{4}^{+}$wet deposition, the simulated deposition is scaled by the ratio between measured and simulated precipitation to eliminate the bias introduced by precipitation fields (Appel et al., 2011).

\section{Results}

\subsection{Optimization performance evaluation}

The optimized $\mathrm{NH}_{3}$ emissions reduce the bias in the $\mathrm{NH}_{3}$ columns between the satellite observation and the model prediction as shown by the decrease in the values of normalized root mean square error (NRMSE) and normalized mean biases (NMBs) in Fig. 2. There are negative biases using 2011 NEI in all 3 months, especially in areas with high emission rates. Although the IMB inversion can lower the NRMSE, it tends to over-adjust and introduce a positive bias, likely because of the coarse resolution and neglect of the impact of transport. The 4D-Var inversion effectively decreases the positive bias and further reduces the NRMSE. The cost function value reduces by 85,46 , and $38 \%$ with the 4D-Var inversion in April, July, and October, respectively. We find that it is more challenging to adjust the emissions in April than in the other 2 months because of the greater differences in the magnitude and the spatial distribution of the emissions. The optimized $\mathrm{NH}_{3}$ emission successfully captures the high $\mathrm{NH}_{3}$ column density in the Southern States (Texas and Oklahoma), reducing the NRMSE by half in that region. Despite the general improvement in the model performance, negative biases in July increase in California's San Joaquin Valley. Scaling up the emission in the San Joaquin Valley will result in high $\mathrm{NH}_{3}$ concentrations downwind even when the local $\mathrm{NH}_{3}$ emissions downwind are zeroed, whereas the IASI-NH${ }_{3}$ observed concentrations downwind are low. The transported hotspot downwind of the San Joaquin Valley in CMAQ only occurs in July, suggesting near-field removal may not be captured at the current resolution, and warrants further investigation. Grid-by-grid comparison between model-simulated $\mathrm{NH}_{3}$ column density using the a priori and optimized estimates with IASI-NH shows improved agreement in both high- and low-emission grid cells after optimization (Fig. S6). It shows that the hybrid inversion approach can alleviate the weakness of direct 4D-Var inversion, which tends to over-adjust high-emission regions and under-adjust low-emission regions, mainly because the IMB inversion provides a better initial state.

The IMB inversion took three iterations to achieve the convergence condition for each month, and subsequently the 4DVar inversion took 10, 4, and 6 iterations for April, July, and October, respectively. Fewer iterations are needed with the hybrid approach than the direct 4D-Var inversion, which typically takes up to 15 to 20 iterations of adjoint simulation (Paulot et al., 2014; Zhang et al., 2018a). The CPU time of a forward simulation is only one-fifth of an adjoint simula- tion. In total, the CPU time required by the hybrid approach is expected to be one-third to two-thirds lower than the direct 4D-Var inversion approach.

\subsection{Optimized estimate of $\mathrm{NH}_{3}$ emissions}

The monthly total $\mathrm{NH}_{3}$ emission in the CONUS increases by $35 \%$ in April, $18 \%$ in July, and $10 \%$ in October for the optimized estimates. Spatially, the distribution for highemission regions shifts from the Midwest in the 2011 NEI to the Southern States in the optimized estimates in April, whereas the hotspot regions remain consistent in July and October (Fig. 3). Regional total emissions are summarized according to the USDA farm production regions, which define the areas with similar crop production activities (Cooter et al., 2012). In general, the regional variation of $\mathrm{NH}_{3}$ emissions in April is dominated by fertilizer application. The optimized estimates in the Corn Belt and Lake States regions are lower than the $2011 \mathrm{NEI}$, where high contributions from fertilizer applications were estimated. In contrast, the optimized estimates are 2-3 times higher than the 2011 NEI estimates in the Delta States and Southern States, where the a priori estimates for $\mathrm{NH}_{3}$ emission from fertilizer application are low. The higher $\mathrm{NH}_{3}$ emission estimates in the Southern States are driven by the enhanced $\mathrm{NH}_{3}$ column densities from IASI over that region. IASI-NH 3 column densities are higher in 2011 than those in adjacent years (Fig. S7), which coincides with the higher surface temperature observed in 2011 (NOAA 2019) (Fig. S8). $\mathrm{NH}_{3}$ emission will increase due to enhanced $\mathrm{NH}_{3}$ volatilization from agricultural lands under warmer conditions (Bash et al., 2013; Shen et al., 2020). In fact, the optimized $\mathrm{NH}_{3}$ emission pattern in April is more consistent with the spatial pattern of inorganic nitrogen fertilizer estimated based on plant demand (Cooter et al., 2012). $\mathrm{NH}_{3}$ emission in 2011 estimated by CMAQ with a $\mathrm{NH}_{3}$ bidirectional exchange model also predicted higher $\mathrm{NH}_{3}$ emission in the Southern States (Shen et al., 2020). The ratio between $\mathrm{NH}_{3}$ emission estimates in Southern States and those within the CONUS is 26 and $18 \%$ in the optimized estimates and estimates including $\mathrm{NH}_{3}$ bidirectional exchange, respectively. In comparison, the ratio is only $10 \%$ in the a priori NEI estimates, suggesting a potential low bias in 2011 NEI. In July, regional differences are smaller except for the Northern Plain and Mountain region. In the Northern Plain, the $\mathrm{NH}_{3}$ emission is $66 \%$ higher in the optimized estimates, driven by the emission increase in hotspot areas with concentrated animal feeding operations (CAFOs) (USDA, 2012; Van Damme et al., 2017, Clarisse et al., 2019). The potential bias in different sectors suggests the need for sectoral inversion when a larger observational dataset becomes available in the future. In October, the relative difference is less than $10 \%$ in most of the regions, indicating that the 2011 NEI appropriately reflects the $\mathrm{NH}_{3}$ emission pattern. There is a significant increase in the $\mathrm{NH}_{3}$ emissions in Mexico during all 3 months. Such an emission increment is crucial to improving 

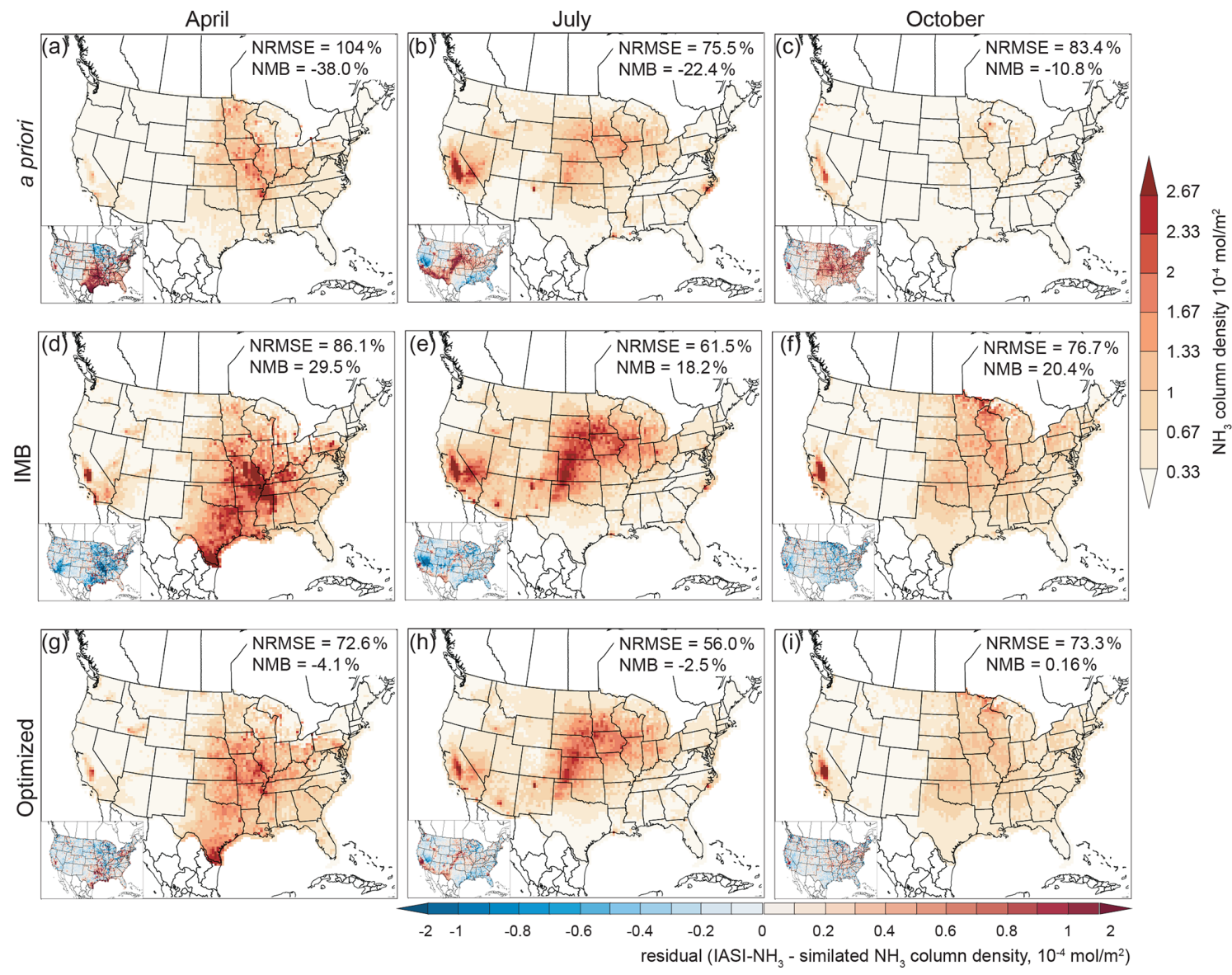

Figure 2. CMAQ-simulated monthly average $\mathrm{NH}_{3}$ column density for April, July, and October 2011 using the a priori emissions (a, b, c), the emissions adjusted by IMB (d, e, f), and the final optimized emissions using the hybrid approach (g, h, i). For comparison with the IASI-NH $\mathrm{NH}_{3}$ retrievals, simulated $\mathrm{NH}_{3}$ columns at the passing time were derived when there were observations in that grid cell. Normalized root mean square error (NRMSE) and normalized mean bias (NMB) between the simulated values and IASI-NH 3 are provided. Residue map (IASI-NH $3-$ simulated $\mathrm{NH}_{3}$ column densities) is shown in the corner of each plot.

the model performance in both Mexico and the southwestern US. However, it was not a goal of this study to determine emissions biases in Mexico given the limited information on $\mathrm{NH}_{3}$ emissions.

The total $\mathrm{NH}_{3}$ emissions in the optimized estimates are 623, 564, and $335 \mathrm{Gg}$ per month in April, July, and October, respectively. In comparison, the emission estimates in the $2011 \mathrm{NEI}$ are 462,475 , and $304 \mathrm{Gg}$ per month for the 3 months. Similar to a bottom-up agricultural $\mathrm{NH}_{3}$ emission inventory (MASAGE_NH 3 ) and two inverse-modeloptimized estimates based on $\mathrm{NH}_{4}^{+}$wet deposition, we find a higher emission in the spring season (Paulot et al., 2014; Gilliland et al., 2006), while others, including the NEI, estimate a summertime peak (Zhu et al., 2013; USEPA, 2015; Cooter et al., 2012; Cao et al., 2020). The large variation between different inventories warrants both improved information on bottom-up inventories and more observations to support inverse model optimization in the spring season. Better knowledge about agricultural activities and more inde- pendent ground and space observations are needed. Besides the a priori emission inventory and observational constraints, the inversion performance will also be affected by other processes (e.g., gas-particle partition, transport, cloud and precipitation, and dry and wet deposition) governing the atmospheric abundance of $\mathrm{NH}_{3}$. Future works refining the pertinent processes will also help improve the optimized $\mathrm{NH}_{3}$ emission estimates. It should also be noted that there are interannual variations in emission inventories developed for different years. The good spatial agreement with IASI-NH indicates that the $2011 \mathrm{NEI}$ captures the $\mathrm{NH}_{3}$ emission pattern in general in these 2 months. Although the inversion is only applied for the selected 3 months, the simulated $\mathrm{NH}_{3}$ column densities using the a priori inventory are consistently lower than the IASI-NH 3 observations in 2011 (Fig. S9), suggesting that the $\mathrm{NH}_{3}$ emission estimates in $2011 \mathrm{NEI}$ may be biased low in other months, too. 

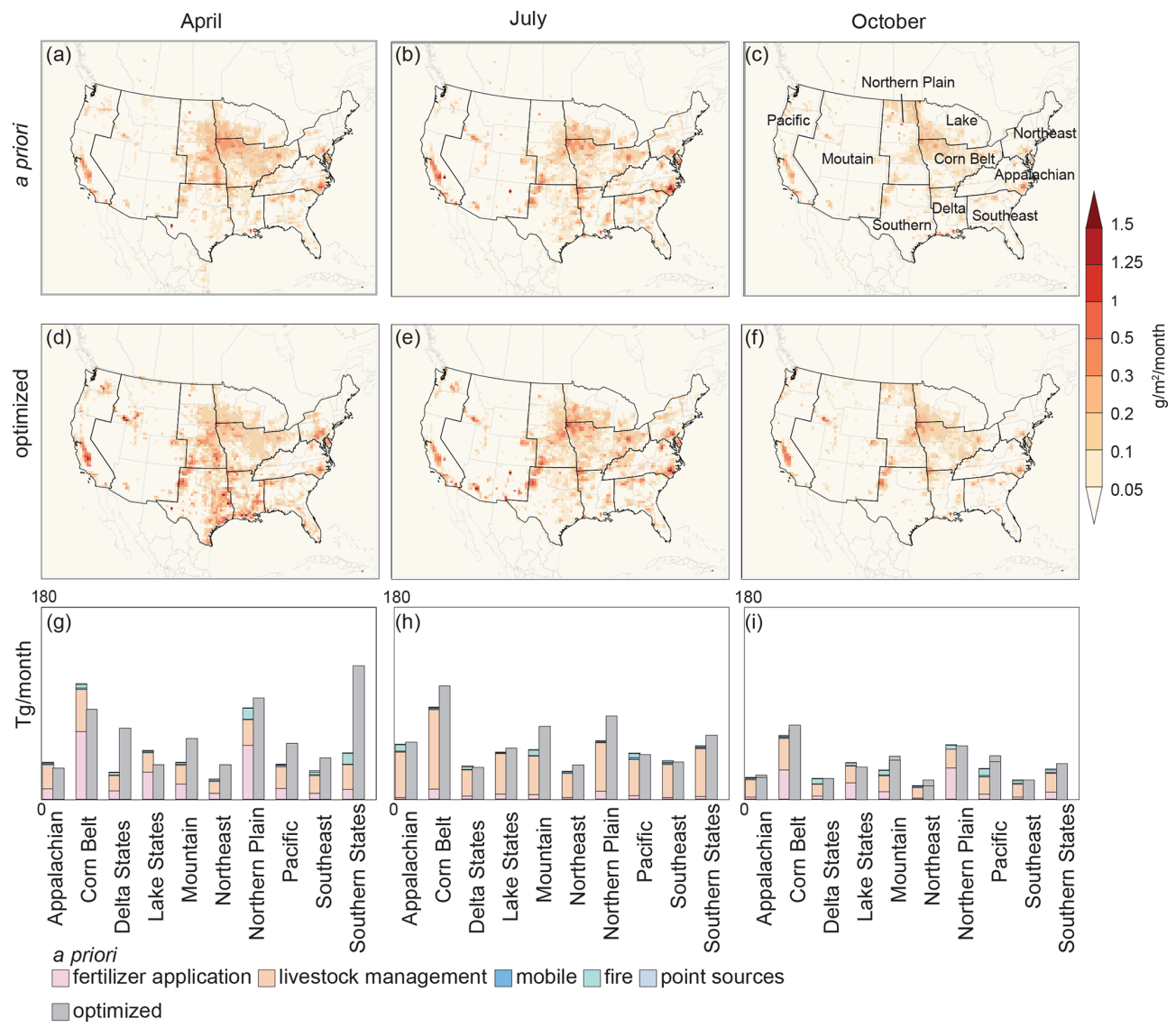

Figure 3. The spatial distribution of monthly total $\mathrm{NH}_{3}$ emission from the a priori (a, b, c) and optimized (d, e, f) estimates in April, July, and October. The total emission based on the a priori and optimized estimates is summarized for each USDA farm production region (g, $\mathbf{h}$, i). The source contributions to total emission are shown for the a priori estimates.

\subsection{Evaluation of the optimized emission estimates against independent datasets}

The robustness of the $\mathrm{NH}_{3}$ emission optimization is evaluated by comparing the model outputs using both the a priori and optimized emission estimates with independent observations. The bias and uncertainties inherited in the CMAQ forward model and its adjoint, as well as the assumptions made about the uncertainties of the a priori emission inventory and IASI- $\mathrm{NH}_{3}$ observations, will all influence the robustness. Here, we choose to evaluate the outputs against (1) biweekly average ambient $\mathrm{NH}_{3}$ concentrations measured by $\mathrm{AMoN}$ and (2) weekly average $\mathrm{NH}_{4}^{+}$wet deposition measured by NADP (Fig. 4).

In general, the optimized $\mathrm{NH}_{3}$ emission reduces the negative NMB when comparing the CMAQ outputs with AMoN $\mathrm{NH}_{3}$ concentration for all 3 months. There is a greater improvement at the high-concentration end than the lowconcentration end because both the IASI satellite and the passive samplers at the AMoN sites have higher uncertainties in areas with low $\mathrm{NH}_{3}$ abundance (Van Damme et al., 2015a; Puchalski et al., 2011). Yet the NRMSE gets higher and $R^{2}$ gets lower in April, indicating a higher spatial variation in the residuals. There is an over-adjustment for sites in Pennsylvania in April, where there is a hotspot observed by IASI on 14 and 15 April. The hotspot possibly came from a large transported plume at a higher altitude from the central US to Pennsylvania (Figs. S10 and S11), which is not measured by ground observations at AMoN sites at biweekly resolution. If that is the case, the hybrid inverse modeling framework would have difficulties in reproducing the long-range transport contribution for two reasons. First, local emissions in Pennsylvania would be enhanced in the IMB inversion, and inter-grid transport were neglected at $216 \mathrm{~km}$ by $216 \mathrm{~km}$ resolution. Second, the following 4D-Var inversion very likely reached a local optimal by adjusting emissions from local and surrounding grid cells near the observed hotspot rather than grid cells at distance. Furthermore, the IASI-NH ${ }_{3}$ column densities may be overestimated because vertical profiles with the highest concentrations near the surface were assumed in the retrieval process (Whitburn et al., 2016).

For evaluation against NADP observations, there is a noticeably improved agreement in April, with reduced negative NMB and reduced discrepancies for most of the data pairs. 

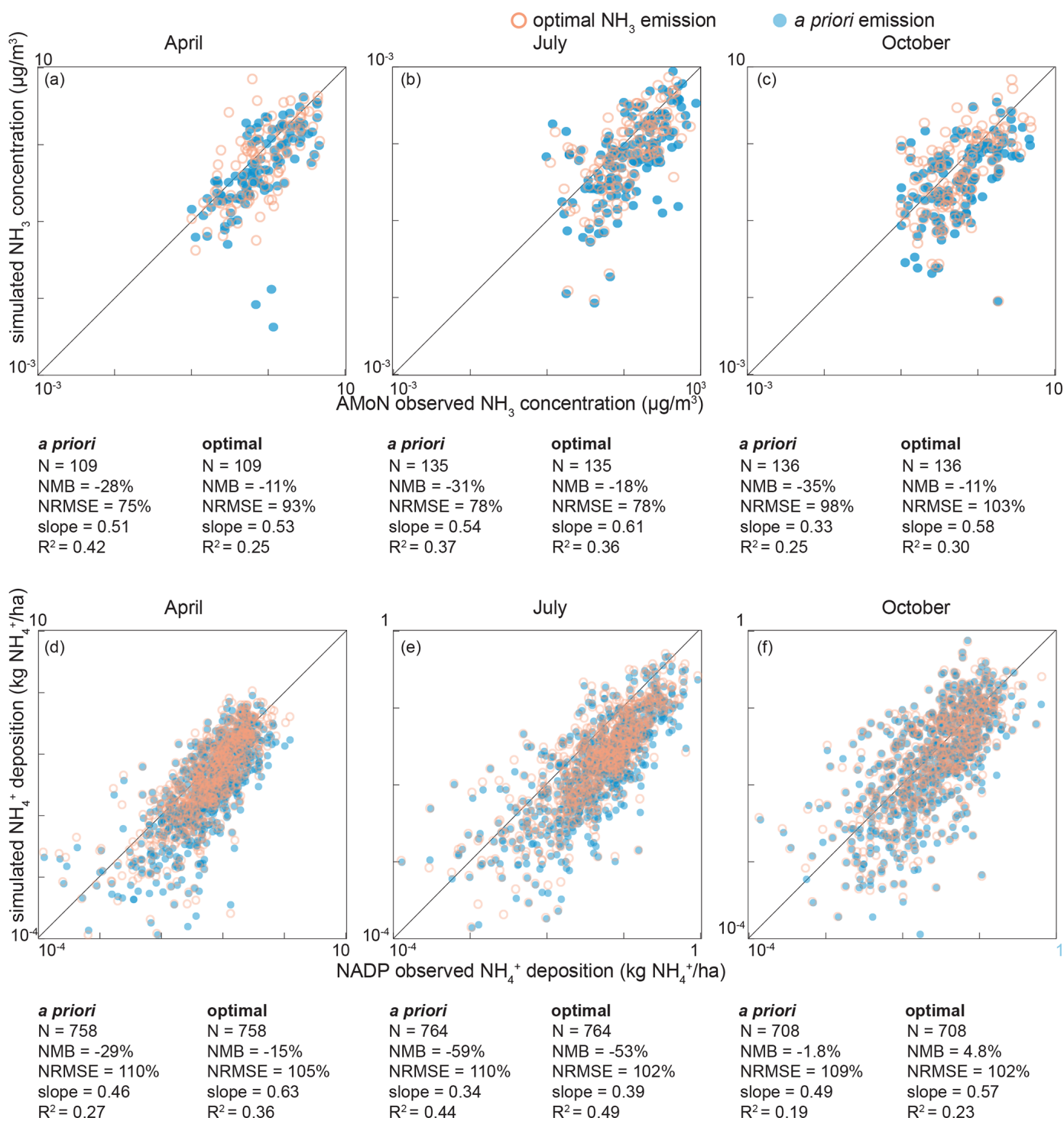

Figure 4. Evaluation of the simulated $\mathrm{NH}_{3}$ surface concentration $(\mathbf{a}, \mathbf{b}, \mathbf{c})$ and $\mathrm{NH}_{4}^{+}$wet deposition $(\mathbf{d}, \mathbf{e}, \mathbf{f})$ against biweekly $\mathrm{NH}_{3}$ concentration observations from $\mathrm{AMoN}$ and weekly $\mathrm{NH}_{4}^{+}$wet deposition observations from NADP, respectively. The orange circles and blue dots represent comparison using the a priori and optimized $\mathrm{NH}_{3}$ emission estimates, respectively. Summary statistics including sample size $(N)$, normalized mean bias (NMB), normalized root mean square error (NRMSE), least square error regression slope and intercept, and $R$ square $\left(R^{2}\right)$ for all comparisons are listed below the plots.

For July, the emission optimization only slightly improved the model performance. For October, the optimization increased the NMB from -1.8 to $4.8 \%$. This indicates that $\mathrm{NH}_{3}$ emission is not the dominant explanatory factor for bias in simulated $\mathrm{NH}_{4}^{+}$wet deposition that is commonly observed in chemical transport models (Appel et al., 2011; Paulot et al., 2014). A better representation of the cloud, precipitation, and deposition processes in the WRF Model and CMAQ is needed to close the gap between simulated and observed $\mathrm{NH}_{4}^{+}$deposition amount. Overall, the improved model operational performance for ambient $\mathrm{NH}_{3}$ suggests that the inverse model optimization applied in this study provides improve- ments in the $\mathrm{NH}_{3}$ emission estimates during all 3 months in most of the CONUS, except in Pennsylvania and surrounding regions in April. The hybrid inverse modeling technique may over-adjust local emissions in hotspots dominated by long-range transport.

\section{Implications}

\subsection{Ambient aerosol concentration}

As a major precursor of ambient aerosol formation, the $\mathrm{NH}_{3}$ emission inventory is believed to be a major source of un- 
certainty in $\mathrm{PM}_{2.5}$ assessment in several parts of the CONUS (Henze et al., 2009; Schiferl et al., 2014; Heald et al., 2012), which can further bias the source contribution assessments on $\mathrm{PM}_{2.5}$-related health impacts (Lee et al., 2015; Zhao et al., 2020). Comparison of the simulated $\mathrm{PM}_{2.5}$ mass concentration using the a priori and optimized $\mathrm{NH}_{3}$ emission estimates shows that the $\mathrm{NH}_{3}$ emission bias in April is a major factor for bias in the modeled $\mathrm{PM}_{2.5}$ concentration leading to high or low bias in ammonium nitrate $\left(\mathrm{NH}_{4} \mathrm{NO}_{3}\right)$ formation (Fig. 5). The relative change of the monthly average $\mathrm{PM}_{2.5}$ concentration is over $5 \%$ in one-fifth of the CONUS, including an increase in the Northeast, the Pacific West, the Rocky Mountains, part of Texas, and the Gulf Coast region, and a decrease in the Midwest. For most of these regions, over $90 \%$ of the change is driven by the change in concentration of $\mathrm{NH}_{4}^{+}$and $\mathrm{NO}_{3}^{-}$.

Comparison of the simulated monthly average $\mathrm{NH}_{4}^{+}$and $\mathrm{NO}_{3}^{-}$concentration using the a priori estimates against ambient monitoring network data (USEPA, 2018) shows that there is a high bias in the Midwest region and Pennsylvania state, and a low bias for the rest of the sites (Table 1). Simulations using the optimized $\mathrm{NH}_{3}$ emission estimates reduce the high bias in the Midwest region but exacerbate the high bias in Pennsylvania state and the surrounding areas. For the other sites, the impact of optimization is mixed but minor in general.

For the Midwest, our optimized $\mathrm{NH}_{3}$ emission is $12 \%$ lower than the 2011 NEI, leading to a 5-30\% decrease in $\mathrm{NH}_{4}^{+}$and $\mathrm{NO}_{3}^{-}$concentration. Overestimation of $\mathrm{NO}_{3}^{-}$in the Midwest has been recognized in previous model evaluations. Previous studies have attempted to moderate the high bias by lowering the nitric acid $\left(\mathrm{HNO}_{3}\right)$ concentration through either lowering both the daytime and nighttime $\mathrm{HNO}_{3}$ formation rate or raising the deposition removal rate (Heald et al., 2012; Zhang et al., 2012; Walker et al., 2012). It was found that such modification in the model parameterization cannot fully account for the overestimation (Heald et al., 2012; Zhang et al., 2012; Walker et al., 2012). Our study implies that the springtime overestimation can partly be explained by the overestimation in $\mathrm{NH}_{3}$ emissions which drives the high bias in $\mathrm{NH}_{4} \mathrm{NO}_{3}$ formation.

The large increase of the $\mathrm{NH}_{4} \mathrm{NO}_{3}$ concentration in Pennsylvania state and the surrounding areas is due to the overamplified local $\mathrm{NH}_{3}$ emissions in the optimized estimates to match the high $\mathrm{NH}_{3}$ column density in IASI- $\mathrm{NH}_{3}$ 2011, as discussed earlier. It leads to a higher magnitude of biases in $\mathrm{NH}_{4}^{+}$and $\mathrm{NO}_{3}^{-}$concentration as compared to ground measurements. The fact that the simulated ambient $\mathrm{NH}_{3}$ concentration, $\mathrm{NH}_{4}^{+}$concentration, and $\mathrm{NH}_{4}^{+}$wet deposition using the optimized $\mathrm{NH}_{3}$ estimates are biased high in comparison with independent ground measurements suggests the enhanced $\mathrm{NH}_{3}$ abundance observed from IASI is possibly driven by long-range transport at higher altitudes instead of local surface emissions.
For the rest of the CONUS, there is only a slight impact of the optimization on simulated $\mathrm{NH}_{4} \mathrm{NO}_{3}$ formation. For example, although the $\mathrm{NH}_{3}$ emission is doubled in the San Joaquin Valley in California, the modeled $\mathrm{NH}_{4}^{+}$and $\mathrm{NO}_{3}^{-}$ concentrations are still biased low using the optimized estimates. A sensitivity test using GEOS-Chem shows that the San Joaquin Valley region is nitric-acid-limited instead of ammonia-limited (Walker et al., 2012), suggesting that there is an underestimation in $\mathrm{HNO}_{3}$ formation. A comparison of the simulated and measured speciated $\mathrm{PM}_{2.5}$ shows that there is a low bias in non-volatile cation concentrations at the sites in the San Joaquin Valley, limiting the formation of $\mathrm{NH}_{4} \mathrm{NO}_{3}$ through gas-particle partitioning (Chen et al., 2019). Thus, attempts to close the gap between the simulated and monitored $\mathrm{NH}_{4}^{+}$and $\mathrm{NO}_{3}^{-}$concentrations by scaling $\mathrm{NH}_{3}$ emission alone are ineffective and might lead to an overestimation in local $\mathrm{NH}_{3}$ emissions.

For July and October, there is a very limited difference between the simulated $\mathrm{PM}_{2.5}$ concentration using the optimized and a priori $\mathrm{NH}_{3}$ emission estimates, as expected, because the change in $\mathrm{NH}_{3}$ emission is minor. There are only 1 and $4 \%$ of the CONUS with a relative change in $\mathrm{PM}_{2.5}$ concentration over $5 \%$, respectively. This result shows that the uncertainty in $\mathrm{NH}_{3}$ emission estimates is moderate and is not a major contributor to biases in modeled $\mathrm{PM}_{2.5}$ in July and October.

\subsection{Reactive nitrogen deposition}

The uncertainties in $\mathrm{NH}_{3}$ emission inventory also impact the reactive nitrogen $(\mathrm{Nr})$ deposition assessment, which informs the ecosystem impacts evaluation and effective mitigation actions (Ellis et al., 2013). To evaluate the impact of the $\mathrm{NH}_{3}$ emission optimization on simulated $\mathrm{Nr}$ deposition, the $\mathrm{Nr}$ deposition amount simulated using optimized and a priori emission estimates is analyzed in all biodiversityprotected areas designated by the USGS (Fig. S12) within the CONUS (USGS, 2018). In total, the $\mathrm{Nr}$ deposition increased by 27,9 , and $5 \%$ on average in these protected areas in April, July, and October, respectively. A regional comparison based on the Level I ecoregions (Pardo et al., 2015) shows that the deposition increment is the highest in the Tropical Wet Forests $(+64 \%)$, followed by the Great Plain region $(+46 \%)$, in April (Fig. 6). Although the overall increase is small in July and October, the increment can be high in individual ecoregions, including Southern Semiarid Highlands ( $+95 \%$ in July) and Temperate Sierras ( $+62 \%$ in July). In addition to the increment in deposition amount, higher $\mathrm{NH}_{3}$ emission, especially in intensive agriculture regions, may indicate higher source contribution from agricultural $\mathrm{NH}_{3}$ than previous estimates (Lee et al., 2016).

Driven by the increase in the reduced form of $\mathrm{Nr}\left(\mathrm{NH}_{3}\right.$ and $\mathrm{NH}_{4}^{+}$) deposition, a higher share of the reduced form of $\mathrm{Nr}$ to the total $\mathrm{Nr}$ deposition is found in most of the ecoregions for all 3 months than in the NEI-based estimates. More detri- 

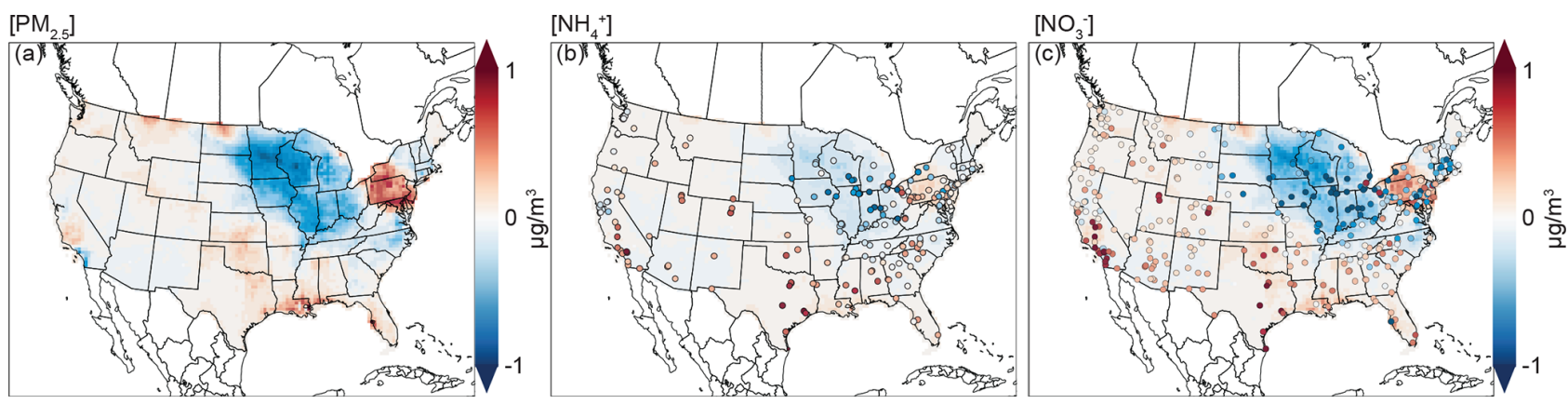

Figure 5. The changes in monthly average $\mathrm{PM}_{2.5}, \mathrm{NH}_{4}^{+}$, and $\mathrm{NO}_{3}^{-}$mass concentration in April due to the $\mathrm{NH}_{3}$ emission adjustment in the optimized estimates. The change is defined as conc optimized $_{-}$conc $_{\text {a priori }}$, where conc $_{\text {optimized }}$ and conc a priori $_{\text {represent the simulated }}$ monthly average mass concentration using the optimized and a priori $\mathrm{NH}_{3}$ emission estimates, respectively. The difference between the observed $\mathrm{NH}_{4}^{+}$and $\mathrm{NO}_{3}^{-}$mass concentration and simulated concentrations using the a priori $\mathrm{NH}_{3}$ emission (conc $\mathrm{obs}_{\mathrm{ob}}-\mathrm{conc}_{\mathrm{a}}$ priori, where conc $_{\text {obs }}$ represents the observed monthly average mass concentration) is overlaid using colored dots with the same color scheme.

Table 1. Statistical summary of the correlation between simulated monthly average $\mathrm{NH}_{4}^{+}$and $\mathrm{NO}_{3}^{-}$concentrations and observations in April*.

\begin{tabular}{|c|c|c|c|c|c|c|}
\hline \multirow[t]{2}{*}{$\mathrm{NH}_{4}^{+}$} & \multicolumn{2}{|c|}{ Midwest } & \multicolumn{2}{|c|}{ Penn } & \multicolumn{2}{|c|}{ Other } \\
\hline & a priori & optimized & a priori & optimized & a priori & optimized \\
\hline $\mathrm{N}$ & \multicolumn{2}{|c|}{47} & \multicolumn{2}{|c|}{37} & \multicolumn{2}{|c|}{115} \\
\hline NMB & 0.27 & 0.22 & 0.00 & 0.07 & -0.35 & -0.35 \\
\hline NRMSE & 0.40 & 0.35 & 0.28 & 0.30 & 0.45 & 0.44 \\
\hline slope & 0.52 & 0.54 & 0.41 & 0.39 & 0.60 & 0.65 \\
\hline$R^{2}$ & 0.57 & 0.65 & 0.24 & 0.18 & 0.25 & 0.28 \\
\hline \multirow[t]{2}{*}{$\mathrm{NO}_{3}^{-}$} & \multicolumn{2}{|c|}{ Midwest } & \multicolumn{2}{|c|}{ Penn } & \multicolumn{2}{|c|}{ Other } \\
\hline & a priori & optimized & a priori & optimized & a priori & optimized \\
\hline $\mathrm{N}$ & \multicolumn{2}{|c|}{69} & \multicolumn{2}{|c|}{38} & \multicolumn{2}{|c|}{240} \\
\hline NMB & 0.64 & 0.55 & 0.25 & 0.43 & -0.39 & -0.38 \\
\hline NRMSE & 0.96 & 0.88 & 0.66 & 0.73 & 0.63 & 0.65 \\
\hline slope & 0.44 & 0.46 & 0.29 & 0.29 & 0.62 & 0.55 \\
\hline$R^{2}$ & 0.76 & 0.78 & 0.33 & 0.31 & 0.28 & 0.25 \\
\hline
\end{tabular}

* The correlation between observed concentrations and simulated ones based on a priori and optimized $\mathrm{NH}_{3}$ emission estimates is compared. The sites are grouped as the Midwest region, Pennsylvania state and surrounding areas, and other areas.

mental impacts on sensitive species and biodiversity are expected when this change in dominant $\mathrm{Nr}$ form is considered in addition to the increase in magnitude because the growth of many sensitive plant species will be inhibited by a high $\mathrm{NH}_{4}^{+}$-to- $\mathrm{NO}_{3}^{-}$ratio in soil and water (Bobbink and Hicks, 2014).

\section{Conclusions}

We apply the newly developed multiphase adjoint of the CMAQ v5.0 chemical transport model and $\mathrm{NH}_{3}$ column observations from the satellite-borne IASI to optimize $\mathrm{NH}_{3}$ emissions estimates in the CONUS using a hybrid in- version modeling approach. The approach consists of a coarse-resolution iterative mass balance inversion $(216 \mathrm{~km}$ by $216 \mathrm{~km})$ and a fine-resolution 4D-VAR inversion $(36 \mathrm{~km}$ by $36 \mathrm{~km}$ ) and is performed using IASI-NH $\mathrm{NH}_{3}$ observations in April, July, and October. The hybrid approach overcomes the over-adjusting problem for high-emission areas in the direct 4D-Var method and reduces the computational cost, but it may introduce over-adjustment in special cases where the $\mathrm{NH}_{3}$ abundance is dominated by transport instead of local emissions.

We use the $\mathrm{NH}_{3}$ emission from 2011 NEI, commonly used in regional and national simulations and assessments as the a priori emission. We find that the optimized $\mathrm{NH}_{3}$ emission inventory differs greatly with the 2011 NEI in April. The 


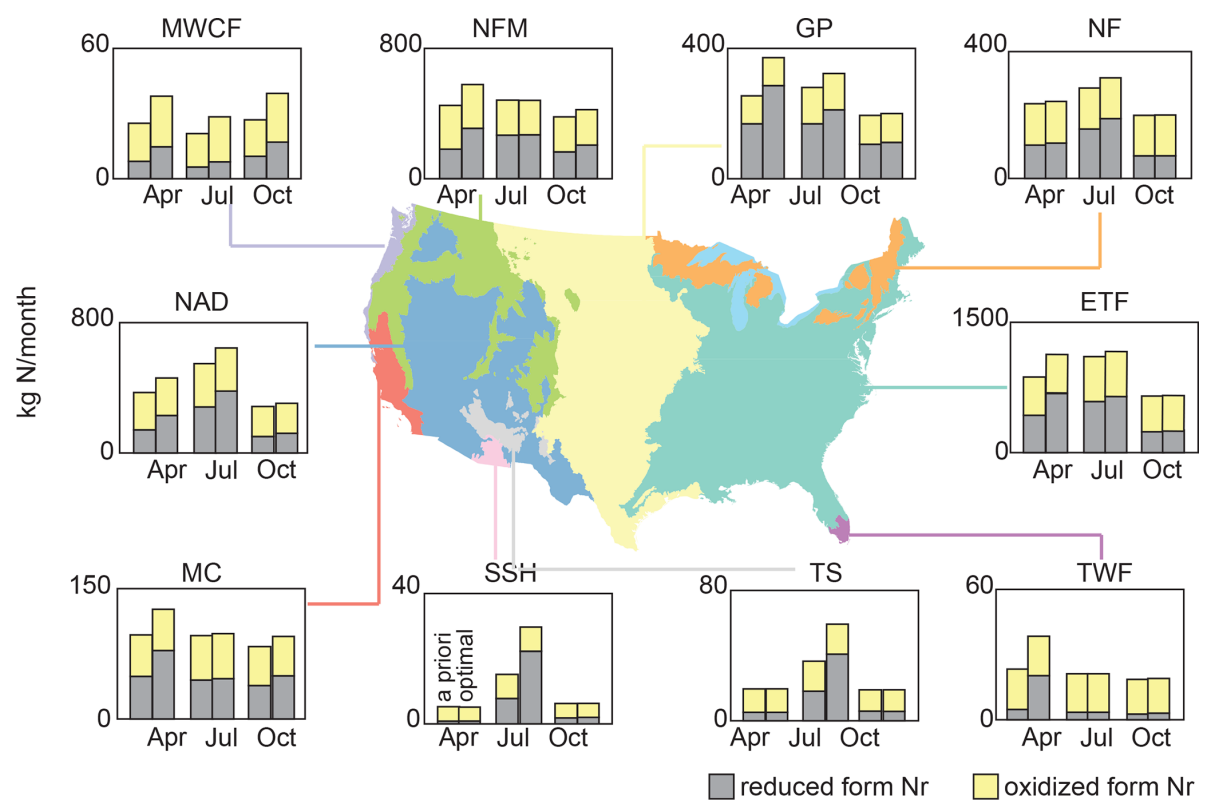

Figure 6. The changes in the simulated monthly reactive nitrogen $(\mathrm{Nr})$ deposition amount in protected areas for biodiversity conservation caused by the emission adjustment in April, July, and October. For each month, the left bar is for the a priori deposition amounts and the right bar is for the optimized deposition amounts. The deposition is grouped for 10 Level I ecoregions defined by the Commission for Environmental Cooperation, including Northern Forests (NF), Great Plains (GP), Northwestern Forested Mountains (NFM), Marine West Coast Forest (MWCF), North American Deserts (NAD), Mediterranean California (MC), Southern Semiarid Highlands (SSH), Temperate Sierras (TS), and Tropical Wet Forests (TWF).

emission in the Midwest is overestimated and the emission in the Southern States is underestimated in the 2011 NEI. Overall, the optimized emission is $35 \%$ higher in April. The optimized emission estimates in July and October are also higher (18 and $10 \%)$ than the 2011 NEI estimates, but the spatial distribution agrees well. The IASI-NH $\mathrm{NH}_{3}$ observations indicate a consistent underestimation of $\mathrm{NH}_{3}$ emissions in California's San Joaquin Valley in all 3 months; however, the inverse modeling fails to properly scale up the emissions in July. The evaluation of simulation outputs against ground measurements including ambient $\mathrm{NH}_{3}$ concentrations from AMoN and $\mathrm{NH}_{4}^{+}$wet deposition from NADP shows that the optimized $\mathrm{NH}_{3}$ emission estimates reduce the NMB between model outputs and independent observations, especially in April. The NRMSE remains high, indicating (1) the potential to further optimize $\mathrm{NH}_{3}$ emission estimates when more representative observations of ambient $\mathrm{NH}_{3}$ abundance become available and (2) the need to address the uncertainties in other processes affecting the $\mathrm{NH}_{3}$ abundance, such as gas-particle partitioning, dry and wet deposition, and in-cloud processes.

Application of the optimized $\mathrm{NH}_{3}$ emission estimates also yields a better agreement between the simulated and observed $\mathrm{PM}_{2.5}$ concentration in April in the Midwest region by improving the model performance on simulated $\mathrm{NH}_{4}^{+}$and $\mathrm{NO}_{3}^{-}$. This is consistent with previous findings that the uncertainty in $\mathrm{NH}_{3}$ emission is a key factor limiting the model performance of $\mathrm{PM}_{2.5}$. The optimized $\mathrm{NH}_{3}$ emission estimates in general increase the $\mathrm{Nr}$ deposition amount and the relative importance of reduced-form $\mathrm{Nr}$, highlighting the importance of constraining $\mathrm{NH}_{3}$ emission estimates for accurately assessing nitrogen deposition and ecosystem health over sensitive regions.

Data availability. The IASI/Metop-A $\mathrm{NH}_{3}$ total column Level 2 data are available at the IASI portal provided by the AERIS data infrastructure (https://iasi.aeris-data.fr/NH3_IASI_A_data; ULB, 2018). Independent observations for evaluation - including surface $\mathrm{NH}_{3}$ concentrations, $\mathrm{NH}_{4}^{+}$wet depositions, and speciated $\mathrm{PM}_{2.5}$ concentrations - are available from the NADP website and Air Quality System (http://nadp.slh.wisc.edu/data/AMoN/, NADP, 2014; http://nadp.slh.wisc.edu/data/NTN/, NADP, 2019; https://aqs. epa.gov/aqsweb/documents/data_api.html, USEPA, 2018).

Supplement. The supplement related to this article is available online at: https://doi.org/10.5194/acp-21-2067-2021-supplement.

Author contributions. AR and YC conceived the study. YC, AR, $\mathrm{HZ}$, and JK contributed to the design the method. YC conducted the inverse modeling and data analysis. LC, PFC, and MVD are responsible for the IASI-NH 3 data. SC, SZ, AH, MR, MT, DH, PP, JR, AN, AP, SN, JB, KF, GC, CS, TC, and AR developed the adjoint model of CMAQ. YC prepared the manuscript, with discussions and 
comments from HS, AR, JK, YH, SC, SZ, JS, and GP. All authors gave approval to the final version of the manuscript.

Competing interests. The authors declare that they have no conflict of interest.

Disclaimer. Contents of this publication are solely the responsibility of the grantee and do not necessarily represent the official views of the supporting agencies. Further, the US government does not endorse the purchase of any commercial products or services mentioned in the publication.

Acknowledgements. The authors acknowledge the AERIS data infrastructure for providing access to the IASI data in this study. ULB has been supported by the Belgian State Federal Office for Scientific, Technical and Cultural Affairs (Prodex arrangement IASI.FLOW). Lieven Clarisse and Martin Van Damme are respectively research associate and postdoctoral researcher with the Belgian F.R.S-FNRS.

Financial support. This research has been supported by the United States Environmental Protection Agency (grant no. R83588001), the National Aeronautics and Space Administration (grant no. NNX16AQ29G), and the China Scholarship Council (grant no. 201606010393).

Review statement. This paper was edited by Bryan N. Duncan and reviewed by two anonymous referees.

\section{References}

Appel, K. W., Foley, K. M., Bash, J. O., Pinder, R. W., Dennis, R. L., Allen, D. J., and Pickering, K.: A multi-resolution assessment of the Community Multiscale Air Quality (CMAQ) model v4.7 wet deposition estimates for 2002-2006, Geosci. Model Dev., 4, 357-371, https://doi.org/10.5194/gmd-4-357-2011, 2011.

Bash, J. O., Cooter, E. J., Dennis, R. L., Walker, J. T., and Pleim, J. E.: Evaluation of a regional air-quality model with bidirectional $\mathrm{NH}_{3}$ exchange coupled to an agroecosystem model, Biogeosciences, 10, 1635-1645, https://doi.org/10.5194/bg-101635-2013, 2013.

Bobbink, R. and Hicks, W. K.: Factors affecting nitrogen deposition impacts on biodiversity: an overview, in: Nitrogen deposition, critical loads and biodiversity, edited by: Sutton, M. A., Mason, K. E., Sheppard, L. J., Sverdrup, H., Haeuber, R., and Hicks, W. K., Springer Netherlands, Dordrecht, 127-138, 2014.

Brasseur, G. P. and Jacob, D. J.: Modeling of atmospheric chemistry, Cambridge University Press, Cambridge, UK, 520-525, 2017.

Byrd, R. H., Lu, P., Nocedal, J., and Zhu, C.: A limited memory algorithm for bound constrained optimization, SIAM J. Sci. Comput., 16, 1190-1208, https://doi.org/10.1137/0916069, 1995.
Byun, D. and Schere, K. L.: Review of the governing equations, computational algorithms, and other components of the models3 Community Multiscale Air Quality (CMAQ) modeling system, Appl. Mech. Rev., 59, 51-77, https://doi.org/10.1115/1.2128636, 2006.

Cao, H., Henze, D. K., Shephard, M. W., Dammers, E., CadyPereira, K., Alvarado, M., Lonsdale, C., Luo, G., Yu, F., Zhu, L., Danielson, C. G., and Edgerton, E. S.: Inverse modeling of NH3 sources using CrIS remote sensing measurements, Environ. Res. Lett., 15, 104082, 10.1088/1748-9326/abb5cc, 2020.

Chen, Y., Shen, H., and Russell, A. G.: Current and future responses of aerosol ph and composition in the U.S. to declining $\mathrm{SO}_{2}$ emissions and increasing $\mathrm{NH}_{3}$ emissions, Environ. Sci. Technol., 53, 9646-9655, https://doi.org/10.1021/acs.est.9b02005, 2019.

Chen, Y., Shen, H., Shih, J.-S., Russell, A. G., Shao, S., Hu, Y., Odman, M. T., Nenes, A., Pavur, G. K., Zou, Y., Chen, Z., Smith, R. A., Burtraw, D., and Driscoll, C. T.: Greater contribution from agricultural sources to future reactive nitrogen deposition in the United States, Earths Future, 8, e2019EF001453, https://doi.org/10.1029/2019EF001453, 2020.

Clarisse, L., Clerbaux, C., Dentener, F., Hurtmans, D., and Coheur, P. F.: Global ammonia distribution derived from infrared satellite observations, Nat. Geosci., 2, 479-483, https://doi.org/10.1038/ngeo551, 2009.

Clarisse, L., Shephard, M. W., Dentener, F., Hurtmans, D., CadyPereira, K., Karagulian, F., Van Damme, M., Clerbaux, C., and Coheur, P.-F.: Satellite monitoring of ammonia: A case study of the San Joaquin Valley, J. Geophys. Res., 115, D13302, https://doi.org/10.1029/2009JD013291, 2010.

Clarisse, L., Van Damme, M., Clerbaux, C., and Coheur, P.F.: Tracking down global $\mathrm{NH}_{3}$ point sources with windadjusted superresolution, Atmos. Meas. Tech., 12, 5457-5473, https://doi.org/10.5194/amt-12-5457-2019, 2019.

Cooper, M., Martin, R. V., Padmanabhan, A., and Henze, D. K.: Comparing mass balance and adjoint methods for inverse modeling of nitrogen dioxide columns for global nitrogen oxide emissions, J. Geophys. Res.-Atmos., 122, 4718-4734, https://doi.org/10.1002/2016jd025985, 2017.

Cooter, E. J., Bash, J. O., Benson, V., and Ran, L.: Linking agricultural crop management and air quality models for regional to national-scale nitrogen assessments, Biogeosciences, 9, 40234035, https://doi.org/10.5194/bg-9-4023-2012, 2012.

Dammers, E., Palm, M., Van Damme, M., Vigouroux, C., Smale, D., Conway, S., Toon, G. C., Jones, N., Nussbaumer, E., Warneke, T., Petri, C., Clarisse, L., Clerbaux, C., Hermans, C., Lutsch, E., Strong, K., Hannigan, J. W., Nakajima, H., Morino, I., Herrera, B., Stremme, W., Grutter, M., Schaap, M., Wichink Kruit, R. J., Notholt, J., Coheur, P.-F., and Erisman, J. W.: An evaluation of $\mathrm{IASI}_{-\mathrm{NH}}$ with ground-based Fourier transform infrared spectroscopy measurements, Atmos. Chem. Phys., 16, 10351-10368, https://doi.org/10.5194/acp-16-10351-2016, 2016.

Dammers, E., Shephard, M. W., Palm, M., Cady-Pereira, K., Capps, S., Lutsch, E., Strong, K., Hannigan, J. W., Ortega, I., Toon, G. C., Stremme, W., Grutter, M., Jones, N., Smale, D., Siemons, J., Hrpcek, K., Tremblay, D., Schaap, M., Notholt, J., and Erisman, J. W.: Validation of the CrIS fast physical $\mathrm{NH}_{3}$ retrieval with ground-based FTIR, Atmos. Meas. Tech., 10, 2645-2667, https://doi.org/10.5194/amt-10-2645-2017, 2017. 
Dammers, E., McLinden, C. A., Griffin, D., Shephard, M. W., Van Der Graaf, S., Lutsch, E., Schaap, M., Gainairu-Matz, Y., Fioletov, V., Van Damme, M., Whitburn, S., Clarisse, L., CadyPereira, K., Clerbaux, C., Coheur, P. F., and Erisman, J. W.: $\mathrm{NH}_{3}$ emissions from large point sources derived from CrIS and IASI satellite observations, Atmos. Chem. Phys., 19, 12261-12293, https://doi.org/10.5194/acp-19-12261-2019, 2019.

Ellis, R. A., Jacob, D. J., Sulprizio, M. P., Zhang, L., Holmes, C. D., Schichtel, B. A., Blett, T., Porter, E., Pardo, L. H., and Lynch, J. A.: Present and future nitrogen deposition to national parks in the United States: critical load exceedances, Atmos. Chem. Phys., 13, 9083-9095, https://doi.org/10.5194/acp13-9083-2013, 2013.

Fountoukis, C. and Nenes, A.: ISORROPIA II: a computationally efficient thermodynamic equilibrium model for $\mathrm{K}^{+}$. $\mathrm{Ca}^{2+}-\mathrm{Mg}^{2+}-\mathrm{NH}_{4}^{+}-\mathrm{Na}^{+}-\mathrm{SO}_{4}^{2-}-\mathrm{NO}_{3}^{-}-\mathrm{Cl}^{-}-\mathrm{H}_{2} \mathrm{O}$ aerosols, Atmos. Chem. Phys., 7, 4639-4659, https://doi.org/10.5194/acp-74639-2007, 2007.

Gilliland, A. B., Wyat Appel, K., Pinder, R. W., and Dennis, R. L.: Seasonal $\mathrm{NH}_{3}$ emissions for the continental united states: Inverse model estimation and evaluation, Atmos. Environ., 40, 49864998, https://doi.org/10.1016/j.atmosenv.2005.12.066, 2006.

Hansen, P. C.: The L-curve and its use in the numerical treatment of inverse problems, in: Computational Inverse Problems in Electrocardiology, edited by: Johnston, P., Adv. Comput. Bioeng., WIT Press, Southampton, UK, 119-142, 1999.

Heald, C. L., Collett Jr., J. L., Lee, T., Benedict, K. B., Schwandner, F. M., Li, Y., Clarisse, L., Hurtmans, D. R., Van Damme, M., Clerbaux, C., Coheur, P.-F., Philip, S., Martin, R. V., and Pye, H. O. T.: Atmospheric ammonia and particulate inorganic nitrogen over the United States, Atmos. Chem. Phys., 12, 10295-10312, https://doi.org/10.5194/acp-12-10295-2012, 2012.

Henze, D. K., Seinfeld, J. H., and Shindell, D. T.: Inverse modeling and mapping US air quality influences of inorganic $\mathrm{PM}_{2.5}$ precursor emissions using the adjoint of GEOS-Chem, Atmos. Chem. Phys., 9, 5877-5903, https://doi.org/10.5194/acp-9-58772009, 2009.

Houlton, B. Z., Boyer, E., Finzi, A. C., Galloway, J., Leach, A., Liptzin, D., Melillo, J., Rosenstock, T. S., Sobota, D., and Townsend, A. R.: Intentional versus unintentional nitrogen use in the United States: trends, efficiency and implications, Biogeochemistry, 114, 11-23, https://doi.org/10.1007/s10533-0129801-5, 2013.

Kelly, J. T., Baker, K. R., Nowak, J. B., Murphy, J. G., Markovic, M. Z., VandenBoer, T. C., Ellis, R. A., Neuman, J. A., Weber, R. J., Roberts, J. M., Veres, P. R., de Gouw, J. A., Beaver, M. R., Newman, S., and Misenis, C.: Fine-scale simulation of ammonium and nitrate over the South Coast Air Basin and San Joaquin Valley of California during CalNex-2010, J. Geophys. Res.-Atmos., 119, 3600-3614, 2014.

Lee, H.-M., Paulot, F., Henze, D. K., Travis, K., Jacob, D. J., Pardo, L. H., and Schichtel, B. A.: Sources of nitrogen deposition in Federal Class I areas in the US, Atmos. Chem. Phys., 16, 525540, https://doi.org/10.5194/acp-16-525-2016, 2016.

Lee, C. J., Martin, R. V., Henze, D. K., Brauer, M., Cohen, A., and van Donkelaar, A.: Response of global particulate-matter-related mortality to changes in local precursor emissions. Environ. Sci. Technol., 49, 4335-4344, https://doi.org/10.1021/acs.est.5b00873, 2015.
Li, C., Martin, R. V., Shephard, M. W., Cady-Pereira, K., Cooper, M. J., Kaiser, J., Lee, C. J., Zhang, L., and Henze, D. K.: Assessing the Iterative Finite Difference Mass Balance and 4D-Var Methods to drive ammonia emissions over North America using synthetic observations, J. Geophys. Res.-Atmos., 124, 42224236, https://doi.org/10.1029/2018jd030183, 2019.

Martin, R. V., Jacob, D. J., Chance, K., Kurosu, T. P., Palmer, P. I., and Evans, M. J.: Global inventory of nitrogen oxide emissions constrained by space-based observations of $\mathrm{NO}_{2}$ columns, J. Geophys. Res.-Atmos., 108, 4537, https://doi.org/10.1029/2003jd003453, 2003.

McQuilling, A. M. and Adams, P. J.: Semi-empirical process-based models for ammonia emissions from beef, swine, and poultry operations in the United States, Atmos. Environ., 120, 127-136, https://doi.org/10.1016/j.atmosenv.2015.08.084, 2015.

NADP: Ambient Ammonia Monitoring Network (AMoN), Wisconsin State Laboratory of Hygiene, 465 Henry Mall, Madison, WI 53706, NADP Program Office, available at: http://nadp.slh.wisc. edu/data/AMoN/ (last access: 22 April 2020), 2014

NADP: National Atmospheric Deposition Program (NRSP-3), Wisconsin State Laboratory of Hygiene, 465 Henry Mall, Madison, WI 53706, NADP Program Office, available at: http://nadp.slh. wisc.edu/data/NTN/ (last access: 22 April 2020), 2019.

NOAA: North American Regional Reanalysis, Asheville, NC, National Oceanic and Atmospheric Administration (NOAA), available at: https://www.ncdc.noaa.gov/data-access/model-data/ model-datasets/north-american-regional-reanalysis-narr (last access: 31 March 2020), 2019.

NOAA: Meteorological Development Laboratory/Office of Science and Technology/National Weather Service/NOAA/U.S. Department of Commerce: TDL U.S. and Canada Surface Hourly Observations, Research Data Archive at the National Center for Atmospheric Research, Computational and Information Systems Laboratory, available at: https://rda.ucar.edu/datasets/ds472.0/, last access: 24 December 2020

Pardo, L. H., Robin-Abbott, M. J., Fenn, M. E., Goodale, C. L., Geiser, L. H., Driscoll, C. T., Allen, E. B., Baron, J. S., Bobbink, R., Bowman, W. D., Clark, C. M., Bowman, W. D., Emmett, B., Gilliam, F. S., Greaver, T. L., Hall, S. J., Lilleskov, E. A., Liu, L. L., Lynch, J. A., Nadelhoffer, K. J., Perakis, S. J., Stoddard, J. L., Weathers, K. C., and Dennis, R. L.: Effects and empirical critical loads of nitrogen for ecoregions of the United States, Environ. Pollut. Ser., 25, 129-169, https://doi.org/10.1007/97894-017-9508-1_5, 2015.

Paulot, F., Jacob, D. J., and Henze, D. K.: Sources and processes contributing to nitrogen deposition: an adjoint model analysis applied to biodiversity hotspots worldwide, Environ. Sci. Technol., 47, 3226-3233, https://doi.org/10.1021/es3027727, 2013.

Paulot, F., Jacob, D. J., Pinder, R. W., Bash, J. O., Travis, K., and Henze, D. K.: Ammonia emissions in the United States, European Union, and China derived by highresolution inversion of ammonium wet deposition data: Interpretation with a new agricultural emissions inventory (MASAGE_NH3), J. Geophys. Res.-Atmos., 119, 4343-4364, https://doi.org/10.1002/2013jd021130, 2014.

Puchalski, M. A., Sather, M. E., Walker, J. T., Lehmann, C. M., Gay, D. A., Mathew, J., and Robarge, W. P.: Passive ammonia monitoring in the United States: comparing three dif- 
ferent sampling devices, J. Environ. Monit., 13, 3156-3167, https://doi.org/10.1039/c1em10553a, 2011.

Schiferl, L. D., Heald, C. L., Nowak, J. B., Holloway, J. S., Neuman, J. A., Bahreini, R., Pollack, I. B., Ryerson, T. B., Wiedinmyer, C., and Murphy, J. G.: An investigation of ammonia and inorganic particulate matter in California during the CalNex campaign, J. Geophys. Res.-Atmos., 119, 1883-1902, https://doi.org/10.1002/2013jd020765, 2014

Shen, H., Chen, Y., Hu, Y., Ran, L., Lam, S. K., Pavur, G. K., Zhou, F., and Russell, A. G.: Intense Warming Will Significantly Increase Cropland Ammonia Volatilization Threatening Food Security and Ecosystem Health, One Earth, 3, 126-134, https://doi.org/10.1016/j.oneear.2020.06.015, 2020.

Shephard, M. W., Dammers, E., Cady-Pereira, K. E., Kharol, S. K., Thompson, J., Gainariu-Matz, Y., Zhang, J., McLinden, C. A., Kovachik, A., Moran, M., Bittman, S., Sioris, C. E., Griffin, D., Alvarado, M. J., Lonsdale, C., Savic-Jovcic, V., and Zheng, Q.: Ammonia measurements from space with the Crosstrack Infrared Sounder: characteristics and applications, Atmos. Chem. Phys., 20, 2277-2302, https://doi.org/10.5194/acp-202277-2020, 2020.

Shephard, M. W. and Cady-Pereira, K. E.: Cross-track Infrared Sounder (CrIS) satellite observations of tropospheric ammonia, Atmos. Meas. Tech., 8, 1323-1336, https://doi.org/10.5194/amt8-1323-2015, 2015.

Shephard, M. W., McLinden, C. A., Cady-Pereira, K. E., Luo, M., Moussa, S. G., Leithead, A., Liggio, J., Staebler, R. M., Akingunola, A., Makar, P., Lehr, P., Zhang, J., Henze, D. K., Millet, D. B., Bash, J. O., Zhu, L., Wells, K. C., Capps, S. L., Chaliyakunnel, S., Gordon, M., Hayden, K., Brook, J. R., Wolde, M., and Li, S.-M.: Tropospheric Emission Spectrometer (TES) satellite observations of ammonia, methanol, formic acid, and carbon monoxide over the Canadian oil sands: validation and model evaluation, Atmos. Meas. Tech., 8, 5189-5211, https://doi.org/10.5194/amt-8-5189-2015, 2015.

Stevens, C. J.: Nitrogen in the environment, Science, 363, 578-580, https://doi.org/10.1126/science.aav8215, 2019.

ULB: Ammonia total columns retrieved from IASI measurements from the ANNI-NH $\mathrm{N}_{3}-\mathrm{v} 2.2$ retrieval algorithm, Universite Libre de Bruxelles (ULB)/Laboratoire atmosphères, milieux et observations spatiales (LATMOS), available at: https://iasi.aeris-data. fr/NH3_IASI_A_data (last access: 31 March 2020), 2018.

USDA: 2012 Census Ag Atlas Maps - Livestock and Animals, United States Department of Agriculture, National Agricultural Statistics Service, available at: https://www.nass.usda.gov/Publications/AgCensus/2012/ Online_Resources/Ag_Atlas_Maps/Livestock_and_Animals (last access: 31 March 2020), 2012.

USEPA: CMAQ v5.0, US Environmental Protection Agency, Zenodo, https://doi.org/10.5281/zenodo.1079888, 2012.

USEPA: Preparation of Emissions Inventories for the Version 6.1, 2011 Emissions Modeling Platform, US Environmental Protection Agency, available at: https://www.epa.gov/air-emissions-modeling/ 2011-version-61-technical-support-document (last access: 31 March 2020), 2014.

USEPA: 2011 National Emissions Inventory Data \& Documentation, available at: https://www.epa.gov/air-emissions-inventories/ 2011-national-emissions-inventory-nei-data (last access: 31 March 2020), US Environmental Protection Agency Office of Air Quality Planning and Standards, 2015.

USEPA: Air Quality System Data Mart, US Environmental Protection Agency, available at: https://aqs.epa.gov/aqsweb/ documents/data_api.html, last access: 6 July 2018.

USGS: Protected Areas Database of the United States (PADUS) 2.0, U.S. Geological Survey (USGS) Gap Analysis Project (GAP), available at: https://gapanalysis.usgs.gov/padus (last access: 31 March 2020), 2018.

Van Damme, M., Clarisse, L., Heald, C. L., Hurtmans, D., Ngadi, Y., Clerbaux, C., Dolman, A. J., Erisman, J. W., and Coheur, P. F. Global distributions, time series and error characterization of atmospheric ammonia (NH3) from IASI satellite observations, Atmos. Chem. Phys., 14, 2905-2922, https://doi.org/10.5194/acp14-2905-2014, 2014.

Van Damme, M., Clarisse, L., Dammers, E., Liu, X., Nowak, J. B., Clerbaux, C., Flechard, C. R., Galy-Lacaux, C., Xu, W., Neuman, J. A., Tang, Y. S., Sutton, M. A., Erisman, J. W., and Coheur, P. F.: Towards validation of ammonia $\left(\mathrm{NH}_{3}\right)$ measurements from the IASI satellite, Atmos. Meas. Tech., 8, 15751591, https://doi.org/10.5194/amt-8-1575-2015, 2015 a.

Van Damme, M., Erisman, J. W., Clarisse, L., Dammers, E., Whitburn, S., Clerbaux, C., Dolman, A. J., and Coheur, P. F.: Worldwide spatiotemporal atmospheric ammonia $\left(\mathrm{NH}_{3}\right)$ columns variability revealed by satellite, Geophys. Res. Lett., 42, 8660-8668, https://doi.org/10.1002/2015g1065496, 2015b.

Van Damme, M., Whitburn, S., Clarisse, L., Clerbaux, C., Hurtmans, D., and Coheur, P.-F.: Version 2 of the IASI $\mathrm{NH} 3$ neural network retrieval algorithm: near-real-time and reanalysed datasets, Atmos. Meas. Tech., 10, 4905-4914, https://doi.org/10.5194/amt-10-4905-2017, 2017.

Van Damme, M., Clarisse, L., Whitburn, S., Hadji-Lazaro, J., Hurtmans, D., Clerbaux, C., and Coheur, P. F.: Industrial and agricultural ammonia point sources exposed, Nature, 564, 99-103, https://doi.org/10.1038/s41586-018-0747-1, 2018.

Walker, J. M., Philip, S., Martin, R. V., and Seinfeld, J. H.: Simulation of nitrate, sulfate, and ammonium aerosols over the United States, Atmos. Chem. Phys., 12, 11213-11227, https://doi.org/10.5194/acp-12-11213-2012, 2012.

Warner, J. X., Wei, Z., Strow, L. L., Dickerson, R. R., and Nowak, J. B.: The global tropospheric ammonia distribution as seen in the 13-year AIRS measurement record, Atmos. Chem. Phys., 16, 5467-5479, https://doi.org/10.5194/acp-16-5467-2016, 2016.

Whitburn, S., Van Damme, M., Clarisse, L., Bauduin, S., Heald, C. L., Hadji-Lazaro, J., Hurtmans, D., Zondlo, M. A., Clerbaux, C., and Coheur, P. F.: A flexible and robust neural network IASI$\mathrm{NH}_{3}$ retrieval algorithm, J. Geophys. Res.-Atmos., 121, 65816599, https://doi.org/10.1002/2016jd024828, 2016.

Xu, R. T., Tian, H. Q., Pan, S. F., Prior, S. A., Feng, Y. C., Batchelor, W. D., Chen, J., and Yang, J.: Global ammonia emissions from synthetic nitrogen fertilizer applications in agricultural systems: Empirical and process-based estimates and uncertainty, Glob Change Biol., 25, 314-326, https://doi.org/10.1111/gcb.14499, 2019.

Yarwood, G., Sunja, R., Mark, Y., and Gary, Z. W.: Updates to the carbon bond chemical mechanism: CB05, Report to the U.S. Environmental Protection Agency, available at: http://www. 
camx.com/publ/pdfs/cb05_final_report_120805.pdf (last access: 31 March 2020), 2005.

Zhang, L., Jacob, D. J., Knipping, E. M., Kumar, N., Munger, J. W., Carouge, C. C., van Donkelaar, A., Wang, Y. X., and Chen, D.: Nitrogen deposition to the United States: distribution, sources, and processes, Atmos. Chem. Phys., 12, 4539-4554, https://doi.org/10.5194/acp-12-4539-2012, 2012.

Zhang, L., Chen, Y., Zhao, Y., Henze, D. K., Zhu, L., Song, Y., Paulot, F., Liu, X., Pan, Y., Lin, Y., and Huang, B.: Agricultural ammonia emissions in China: reconciling bottom-up and top-down estimates, Atmos. Chem. Phys., 18, 339-355, https://doi.org/10.5194/acp-18-339-2018, 2018a.

Zhang, R., Thompson, T. M., Barna, M. G., Hand, J. L., McMurray, J. A., Bell, M. D., Malm, W. C., and Schichtel, B. A.: Source regions contributing to excess reactive nitrogen deposition in the Greater Yellowstone Area (GYA) of the United States, Atmos. Chem. Phys., 18, 12991-13011, https://doi.org/10.5194/acp-1812991-2018, 2018b.

Zhang, Y., Mathur, R., Bash, J. O., Hogrefe, C., Xing, J., and Roselle, S. J.: Long-term trends in total inorganic nitrogen and sulfur deposition in the US from 1990 to 2010, Atmos. Chem. Phys., 18, 9091-9106, https://doi.org/10.5194/acp-189091-2018, 2018c.
Zhao, S., Russell, M. G., Hakami, A., Capps, S. L., Turner, M. D., Henze, D. K., Percell, P. B., Resler, J., Shen, H., Russell, A. G., Nenes, A., Pappin, A. J., Napelenok, S. L., Bash, J. O., Fahey, K. M., Carmichael, G. R., Stanier, C. O., and Chai, T.: A multiphase CMAQ version 5.0 adjoint, Geosci. Model Dev., 13, 2925-2944, https://doi.org/10.5194/gmd-13-2925-2020, 2020.

Zhu, C., Byrd, R., Lu, P., and Nocedal, J.: Algorithm 778: L-BFGS-B: Fortran subroutines for large-scale boundconstrained optimization, ACM T. Math. Software, 23, 550-560, https://doi.org/10.1145/279232.279236, 1997.

Zhu, L., Henze, D. K., Cady-Pereira, K. E., Shephard, M. W., Luo, M., Pinder, R. W., Bash, J. O., and Jeong, G. R.: Constraining U.S. ammonia emissions using TES remote sensing observations and the GEOS-Chem adjoint model, J. Geophys. Res.-Atmos., 118, 3355-3368, https://doi.org/10.1002/jgrd.50166, 2013.

Zhu, L. Y., Henze, D. K., Bash, J. O., Cady-Pereira, K. E., Shephard, M. W., Luo, M., and Capps, S. L.: Sources and impacts of atmospheric $\mathrm{NH}_{3}$ : current understanding and frontiers for modeling, measurements, and remote sensing in North America, Curr. Pollut. Rep., 1, 95-116, https://doi.org/10.1007/s40726-015-0010-4, 2015. 